DOI: $10.31548 /$ machenergy.2020.01.133-139

\author{
UDC 631.354.2:633.85
}

\title{
DETERMINATION OF INFLUENCE OF MODES OF STORAGE FRUIT AND VEGETABLE PRODUCTS IN ITS CONDITION
}

\author{
V. A. Muzychenko \\ National Scientific Centre «Institute for Agricultural Engineering and Electrification». Ukraine. \\ Speciality of article: 162 - biotechnology and bioengineering. \\ Corresponding author: moozychenko.va@gmal.com
}

Article history: Received - October 2019, Accepted - January 2020.

Bibl. 11, fig. 0, tabl. 0.

Abstract. We analyzed the levels of consumption of fruit and vegetable products and its losses. It proposed to use information from a storage facility on its condition to determine the effect of storage conditions on the condition. Analyzed ways of obtaining information from crop production on her condition. The necessity of providing information on the status of the storage facility, depending on the condition of the storage conditions, as well as the impact on the duration of storage modes in an analytical form. The necessity for the use of storage efficiency as the optimization and simulation mathematical modeling of the impact of external influences on the stored product. The analytical description of the production condition depending on the storage conditions allowing to determine one of modes of storage, depending on the planned storage efficiency remaining under fixed conditions. In the example according to the redox potential of plant raw material with succulent tissues of storage time the technique its exponential approximation. The dependence of the efficiency of its storage mode, which can serve as an objective function in the optimization of these regimes.

The prerequisites for simulation of the effect of external influences on the storage efficiency and optimize storage by the criterion of minimum loss mode if the controlled variables are the length of storage, and the temperature and humidity in the warehouse.

Mathematical models of processes of storage make it possible to adjust the modes during storage and predict the state of the stored object.

Key words: agricultural production, storage, efficiency, modes, mathematical modeling.

\section{Introduction}

Ensure an adequate level of food consumption remains relevant. His may be improved by reducing the loss during storage, which is more advantageous as compared to the expansion of production. The same applies to animal feed.

Further work on improving the loss reduction require analytical description of the storage process.

\section{Formulation of problem}

Investigation of product storage process and the development of new ways it requires an analytical description of the state of the product, depending on the storage conditions and storage process modeling.

Asked to assess and optimize the quality of agricultural products depending on the conditions of its cultivation [9-11].

Some growing conditions influence possible. This dose and timing of fertilizer application [12], agricultural practices, and the like. Basically the same growing conditions - it's climate and weather indicators that influence is not possible, but they are most dependent on timing of field work. Of these, the quality of the crops most significantly affected by harvesting time. Therefore, to study the effect on product quality growing conditions appropriate to use simulation techniques.

\section{Analysis of recent research results}

In 1980 he founded the annual rate of consumption per person in the Soviet Union was considered $146 \mathrm{~kg}$ vegetables and $120 \mathrm{~kg}$ fruit [1]. In 1989 this, but recommended, is the norm in Ukraine $161 \mathrm{~kg}$ vegetables [2]. In fact, in the Soviet Union in 1982 the consumption of vegetables was 101, and the fruit $42 \mathrm{~kg}$ human [3]. According to [2] in 1985, every resident of Ukraine consumes $133 \mathrm{~kg}$ vegetables.

At the same time state leaders recognized that the storage is lost at least one third of production. [4] Gross harvest of fruits and vegetables while approaching the standards of consumption, but the actual consumption of the losses was not enough. In 2000, losses of fruits and vegetables and other plant products with rich fabrics in storage was estimated at $30-50 \%$ [5].

However, according to [6] in Ukraine produced 6.195 million tons of vegetables and melons, and their losses in 2000 amounted to 177,000 tons, or only $2.857 \%$. In 2016 it produced 9.998 million tons of vegetables and melons, and their losses amounted to 1.195 million tons, or $11.95 \%$.

In such negligible losses sustainment level 
vegetables and foodstuffs in melons 2016 the declared at the level of $101.6 \%$, and fruits, berries and grapes $-84.9 \%$.

With cording to other publications modern volume of consumption of fresh vegetables, potatoes and fruits in Ukraine is 50-60\% of the physiological norm. [7]

Potero in storage potatoes, vegetables and fruit make up 20-30\% annually. [8]

Investing in storage products is 2-3 times more efficient than in the expansion of its production.

In contrast to the growing conditions in the storage modes can be influenced to optimize these regimes. This raises the question of the choice of optimization criteria: the minimization of losses (from disease, weight, nutrition), or minimizing the cost of production at the end of the retention period.

In any case, the optimization of the process is necessary to have quality products depending on the storage conditions in the analytical form. However, the results of studying the effect of storage conditions (as, indeed, and growing conditions) in the analytic form are practically absent, e.g. [13-15].

The $[16,17]$ background laid analytical description of the state of the plant product with succulent tissues, depending on its processing and storage conditions. Such a description requires information from the storage facility. For plant products with rich fabrics receive the information requested by measuring the redox potential (ORP) [18-20].

Research change ORP plant products with rich fabrics during storage give reason to use it as an indicator of the quality of products. An exponential dependence on the duration of storage of AFP with a correlation coefficient of 0.997 [21]. Simultaneously experimentally proved matching ORP changes real loss [22]. For plant material, having a lower humidity, an indicator to be determined.

Compliance dynamics ORP plant products with rich fabrics exponential dependence, as well as its compliance with the magnitude of losses [22] provides a basis to use the dynamics of ORP for predicting plant products with rich fabrics.

AFP is not the only indicator of the properties of plant products. Only plant products with succulent tissues resistance measurement can be used [23], the dielectric properties [24] technique [25-27].

Assessment of the status and quality of food products is carried out by drawing the regression equations. The dependences of the potential on growing conditions. Developed corresponding monogram [28-30].

\section{Purpose of research}

When storing any product it is important to be aware of its ability to store and the deadline within which it will have a sufficient level of consumer qualities, to know which of the batches of products under the identity of all the indicators ability to store longer and what to send to the implementation or processing Firstly. Modern methods of predicting the state of the stored products do not provide the ability to track the dynamics of indicators of the quality of stored products.

The object of research is an analytical description of the effect of storage conditions on its efficiency, enabling the use of mathematical modeling to improve product preservation. Mathematical modeling, in turn, will make it possible to evaluate the effect of storage conditions on the state of the storage facility, as far as possible in a timely manner to change these regimes, or to predict the potential products, and therefore have information about whether to continue storing it.

\section{Results of research}

Theoretical analysis of the impact of external influences on biological objects may be based on the physical nature of the processes occurring in the object and the parameters of these effects. An example of such an analysis is given in [31]. Establish a connection of biological indicators of vegetable raw state with the physical storage performance modes are not yet represented analytically possible.

It is therefore proposed to consider the storage process as a black box on which input information on storage conditions, and the output - the indicators characterizing the state of the storage facility.

According to this principle serves to change the ORP example vegetable raw materials with rich fabrics during storage to give an analytical description of the product according to the state of storage modes, and to be able to determine the storage efficiency depending on the factors that affect this efficiency.

At the subsequent discussion we will proceed from the fact that ORP stored object corresponds to the energy of the object.

$$
d P=k_{1} d Q,
$$

where: $\mathrm{P}$ - measure the energy state stored object;

$k_{1}$ - proportionality factor;

$\mathrm{Q}$ - current value of ORP stored object.

The time variation of the energy state during storage is proportional to the difference between the current value of AFP and its steady value, which is the object after its storage for an indefinite time.

$$
d P=k_{2}\left(Q-Q_{\infty}\right) d t
$$

where: $\mathrm{k}_{2}$ - coefficient of proportionality;

Q $\infty$ - steady ORP value of the object,

$\mathrm{t}$ - duration of storage.

From (1) and (2) we have:

$$
k_{1} d Q=k_{2}\left(Q-Q_{\infty}\right) d t \text {. }
$$

designating

$$
\frac{k_{2}}{k_{1}}=-\tau
$$

where: $\tau$ - permanent storage duration.

After separation of variables we obtain the differential equation:

$$
\frac{d Q}{Q-Q_{\infty}}=-\frac{d t}{\tau} .
$$

After its integration we have:

$$
\ln \left(Q-Q_{\infty}\right)=-\frac{t}{\tau}+\ln C
$$




$$
\left(Q-Q_{\infty}\right)=C e^{-\frac{t}{\tau}}
$$

Before the start of the storage, namely, when $\mathrm{t}=0$, the coefficient of the constant of integration is equal to one, since any number to the zero power is equal to unity, the integration constant will correspond to the expression:

$$
\tilde{N}=Q_{0}-Q_{\infty} \text {. }
$$

where: $\mathrm{Q}_{0}-\mathrm{ORP}$ value prior to storage.

In view of the above, we obtain the relationship AFP storage facility on the duration of storage, a constant storage time, as well as on the initial and steady ORP values [32].

$$
Q=Q_{\infty}\left(1-e^{-\frac{t}{\tau}}\right)+Q_{0} e^{-\frac{t}{\tau}}
$$

Ptinuous duration of storage corresponds to the rate of change of production condition during storage, and thus is a measure of its ability to storage. It is important to note that it is obtained as the ratio of the coefficients of proportionality, which gives the relationship between ORP stored object and its energy state.

Comes the ORP value can provide information about the status of the storage facility at equality of his other indicators. The potential ability to be stored in those products, set a higher ORP.

Storage efficiency is defined as the ratio of the difference between the steady-state current value and ORP of the stored object to a difference between the steady-state and its initial value.

$$
Y^{t}=\frac{Q_{\infty}-Q}{Q_{\infty}-Q_{0}} .
$$

where: Yt - storage efficiency for time changes

ORP from its initial value to steady.

From (9) and (10) have storage efficiency dependence on its duration and potential production capacity for storage, expressed by a constant storage time:

$$
Y^{t}=e^{-\frac{t}{\tau}}
$$

For calculation of the duration of storage of products having potential lost, defines a constant storage time, when a predetermined storage efficiency have

$$
t=-\tau \ln Y^{t} \text {. }
$$

Equation (9) has two unknowns that must be determined.

Steady function value (in this case the AFP) can be determined from the measured values of its four

$$
Q_{\infty}=\frac{Q_{2} Q_{3}-Q_{1} Q_{4}}{Q_{2}+Q_{3}-Q_{1}-Q_{4}} .
$$

or of three values

$$
Q_{\infty}=\frac{Q_{2}^{2}-Q_{1} Q_{3}}{2 Q_{2}-Q_{1}-Q_{3}} .
$$

When three dimensions get exhibitors who exactly runs through all three of these points. For interpolation is enough. When calculations using four exhibitor measurements accurately pass through only one data point, but more will be fully taken into account the measurement error, the whole process will be described more precisely as required for extrapolation, and one of the goals of this work has predict the state of the stored products.

Steady function value should also be constant for the calculation of the length exponent storage having a certain initial value.

This technique requires that the interval between observations. If, during the experiment, this condition was not met, to determine the desired point, you can use an interpolation method.

The next step will be to determine the difference between the established and the current value of the function

$$
\Delta Q=Q_{\infty}-Q
$$

The exponential dependence of the difference in duration from the process or from any other argument:

$$
\Delta Q=\lambda e^{\mu t}
$$

where: $\lambda \mu$ - and approximating rates.

Subsequently we define a constant duration of storage, or any other process [33].

$$
\tau=-\frac{1}{\mu}
$$

Coefficients and correlation coefficient for the exponential dependence of AFP on the storage duration correspond to the formulas

$$
\begin{gathered}
\mu=\frac{\sum_{i=1}^{n} t_{i} \ln Q-\frac{1}{n} \sum_{i=1}^{n} t_{i} \sum_{i=1}^{n} \ln Q}{\sum_{i=1}^{n} t_{i}^{2}-\frac{1}{n}\left(\sum_{i} t_{i}\right)^{2}} ; \\
\lambda=\exp \left[\frac{1}{n}\left(\sum_{i=1}^{n} \ln Q-\mu \sum_{i=1}^{n} t_{i}\right)\right] ; \\
r^{2}=\frac{\left[\sum_{i=1}^{n} t_{i} \ln Q-\frac{1}{n} \sum_{i=1}^{n} t_{i} \sum_{i=1}^{n} \ln Q\right]^{2}}{\left[\sum_{i=1}^{n} t_{i}^{2}-\frac{1}{n}\left(\sum_{i=1}^{n} t_{i}\right)^{2}\right]\left[\sum_{i=1}^{n}(\ln Q)^{2}-\frac{1}{n}\left(\sum_{i=1}^{n} \ln Q\right)^{2}\right]} .
\end{gathered}
$$

Experimental verification of the relationship (9) showed that the observation for 19 days ORP changes apples gave the following results: $\mathrm{Q} 0=264,3 \mathrm{mV}, \mathrm{Q} \infty=$ $371,4 \mathrm{mV}, \tau=$ days. According to these data promoted calculation AFP after 54 days of storage, the result $346.5 \mathrm{mV}$. Result respective measuring - $354.0 \mathrm{mV}$. The difference between the estimated value and the actual ORP was $2.88 \%$, which is quite satisfactory considering three-fold excess of storage time over the measurement duration period [21].

Permanent storage time and is an indirect measure of the ability of products to storage.

The expression (9) takes into account the effect on the storage efficiency only its duration. To investigate the influence of other factors on storage process is necessary to determine the influence of these factors in a fixed storage time. All of them were taken into account is impossible, and for each type of product they are different and well-known, but the shelf life is always crucial.

Typically, products with high moisture content greatest influence temperature and low - humidity 
environment.

On products is influenced by other factors, such as the gas composition of the medium, aeration regimes and m. P.

In general, the storage efficiency is described by the dependence

$$
y=f\left(x_{1}, x_{2}, x_{3} \ldots x_{n}\right) .
$$

where: $x_{1}, x_{2}, x_{3} \ldots x_{n}$-indicators of factors affecting on storage efficiency.

The dependence of the efficiency of the storage of its duration, defined based on ORP measurements, gives reason to use this method to obtain analytical relations storage efficiency of other factors.

This entails the need for the approximation of the existing table data corresponding dependencies. The next assumption is that it should be an exhibitor, as the dependence of the most relevant processes occurring in biological objects.

Then for storage efficiency depending on the duration, temperature and ambient humidity

$$
Y^{t, \theta, W}=f(t, \theta, W) .
$$

where: $\theta$ - ambient temperature;

$W$ - ambient humidity,

we have

$$
\begin{aligned}
& Y^{t, \theta, W}=1-e^{-\frac{W}{w}}-e^{-\frac{\theta}{\vartheta}}-e^{-\frac{t}{\tau}}+e^{-\frac{W}{w}} e^{-\frac{\theta}{\vartheta}}+ \\
& +e^{-\frac{W}{w}} e^{-\frac{t}{\tau}}+e^{-\frac{\theta}{\vartheta}} e^{-\frac{t}{\tau}}-e^{-\frac{W}{w}} e^{-\frac{\theta}{\vartheta}} e^{-\frac{t}{\tau}}
\end{aligned}
$$

where: $\vartheta-$ constant temperature change influence environment;

$w$ - constant humidity changes influence environment.

Similar dependencies can be obtained from a larger number of factors influencing the efficiency of storage.

The dependence (23) allows specifying the desired storage efficiency and temperature and humidity in storage to determine the allowable storage time provided that based on the condition of your products from temperature and humidity correspond to the exponent.

$$
t=-\tau \ln \left(1-\frac{y^{t, \theta, w}}{1-e^{-\frac{\theta}{\vartheta}}-e^{-\frac{W}{w}}+e^{-\frac{W}{w}} e^{-\frac{\theta}{\vartheta}}}\right)
$$

Similarly obtained the valid values of humidity and temperature.

$$
\begin{gathered}
\theta=-\vartheta \ln \left(1-\frac{y^{t, \theta, w}}{1-e^{-\frac{W}{w}}-e^{-\frac{t}{\tau}}+e^{-\frac{W}{w}} e^{-\frac{t}{\tau}}}\right) \\
W=-w \ln \left(1-\frac{y^{t, \theta, w}}{1-e^{-\frac{t}{\tau}}-e^{-\frac{\theta}{\vartheta}}+e^{-\frac{t}{\tau}} e^{-\frac{\theta}{\vartheta}}}\right) .
\end{gathered}
$$

According to (23-26) can be used for simulation of the influence of external factors on efficiency of storage.

Using exponents to approximate the results of a study of the influence of designer factors on the efficiency of storage is not the only possible one. The main argument in favor of using one or another form of addiction has its highest correlation ratio.
The dependence of storage efficiency on the temperature and humidity are more consistent with the parabolas, since they most often have an optimum (extremum). However, the principle of using three or more exponential dependencies suitable for determining the effectiveness of the storage and modelling of the process, with other factors influencing this effectiveness.

A parabolic dependence of storage efficiency on temperature

$$
Y^{\theta}=a_{1} \theta^{2}+a_{2} \theta+a_{3},
$$

where: $\mathrm{a}_{1}, \mathrm{a}_{2}$ and $\mathrm{a}_{3}$ - experimental factors, gives the possibility by equating its first derivative to zero to determine the optimal storage temperature

$$
\theta_{\text {opt }}=-\frac{a_{2}}{2 a_{1}} \text {. }
$$

In this case, the storage efficiency may be determined by any known method, including the measurement of ORP.

A similar dependence of storage efficiency from humidity

$$
Y^{W}=m_{1} W^{2}+m_{2} W+m_{3} .
$$

where: $\mathrm{m}_{1}, \mathrm{~m}_{2}$ and $\mathrm{m}_{3}$ - experimental coefficients.

Accordingly, the optimum moisture content in the repository

$$
W_{o p t}=-\frac{m_{2}}{2 m_{1}} .
$$

In the study of the influence of one factor on efficiency of storage the other factors should remain unchanged.

To determine the dependence of storage efficiency from two factors, for example, the temperature and humidity in the vault, you need to determine according to the experimental factors included in the expression (27) from moisture, namely:

$$
\begin{aligned}
& a_{1}=b_{1} W^{2}+b_{2} W+b_{3}, \\
& a_{2}=c_{1} W^{2}+c_{2} W+c_{3}, \\
& a_{3}=d_{1} W^{2}+d_{2} W+d_{3}
\end{aligned}
$$

where: b-b3, c1-c3 and d1-d3 - experimental coefficients.

The dependence of storage efficiency on temperature and humidity

$$
\begin{aligned}
& Y^{\theta, W}=b_{1} W^{2}+b_{2} W+b \theta^{2}+c_{1} W^{2}+ \\
& +c_{2} W+c_{3} \theta+d_{1} W^{2}+d_{2} W+d_{3}
\end{aligned}
$$

This dependence is also easy to be differentiation with the aim of determining an optimum one of the parameters of the environment.

According to (27-34) give the relationship between efficiency of storage, temperature and humidity in the vault, either separately or together.

Thus, the preconditions for storage optimization process, under controlled temperature and humidity storage.

To do this optimization criterion defined with (minimum losses during storage or minimum cost storage process), and to determine the maximum permissible boundary values of adjustable parameters and to develop an algorithm corresponding calculations. 
However, along with the parameters of the medium must also be considered and duration of storage.

Permanent storage duration carries information about the potential ability of an object to storage. The first is biological properties of the object. However, because the duration of storage is largely dependent on the temperature and humidity, these factors should affect the permanent storage duration.

Effect of temperature on a permanent storage duration will correspond expression

$$
\tau=g_{1} \theta^{2}+g_{2} \theta+g_{3} .
$$

where: $g_{1}, g_{2}$ and $g_{3}-$ the experimental factors.

Then the dependence of the efficiency of its storage duration and storage temperature will be

$$
Y^{t, \theta}=e^{-\frac{t}{g_{1} \theta^{2}+g_{2} \theta+g_{3}}} .
$$

where we have the dependence of the duration of storage of the temperature in the storage and storage efficiency

$$
t=-\left(g_{1} \theta^{2}+g_{2} \theta+g_{3}\right) \ln Y^{t, \theta} \text {. }
$$

Effect of humidity on the permanent storage duration will correspond expression

$$
\tau=q_{1} W^{2}+q_{2} W+q_{3}
$$

where: $\mathrm{q}_{1}, \mathrm{q}_{2}$ and $\mathrm{q}_{3}$ - experimental factors.

Similarly, the dependence of the efficiency of storage of its duration and the humidity in storage will

$$
Y^{t, W}=e^{-\frac{t}{q_{1} W^{2}+q_{2} W+q_{3}}} .
$$

where we have the dependence of the duration of storage of the temperature in the storage and storage efficiency, namely:

$$
t=-\left(q_{1} W^{2}+q_{2} W+q_{3}\right) \ln Y^{t, W} .
$$

Based on (27, 29, 31-33, 35 and 37) obtained on the basis of direct measurements of losses during storage. The corresponding dependence of the storage efficiency obtained by measuring the ORP or other indicators of the object state storage will be the following:

the dependence of storage efficiency that is ego duration and temperature in the vault

$$
Y^{t, \theta}=\frac{Q_{\infty}-Q_{\infty}\left(1-e^{-\frac{t}{g_{1} \theta+g_{2} \theta+g_{3}}}\right)+Q_{0} e^{-\frac{t}{g_{1} \theta+g_{2} \theta+g_{3}}}}{Q_{\infty}-Q_{0}},
$$

and the dependence of storage efficiency that is ego duration and humidity in the vault

$$
Y^{t, W}=\frac{Q_{\infty}-Q_{\infty}\left(1-e^{-\frac{t}{q_{1} W+q_{2} W+q_{3}}}\right)+Q_{0} e^{-\frac{t}{q_{1} W+q_{2} W+q_{3}}}}{Q_{\infty}-Q_{0}} .
$$

The expression (35-41) can be used to simulate the storage process vegetable raw materials with rich fabrics. They give the relationship between the three parameters of the four: effectiveness and duration of storage, as well as humidity and temperature in storage, which is sufficient for simulation.

The foregoing is valid at any combination of factors affecting the process and storage can be used to study the process of storing any product.
The abundance of experimental factors explained by the fact that modeling is required to be based on the results of previous studies.

The object is to obtain further analytical work efficiency dependence storage on three factors, namely its duration, as well as temperature and humidity, or any other gaseous medium in the storage.

Experience studies the impact of external influences on the state of the storage object shows that it is these factors have the most significant impact. However, not excluded the need to study the simultaneous effect on the storage facility is four or more factors.

\section{Conclusions}

1. Consumption of vegetables and fruits in Ukraine lags behind the rational norms.

2. Most cheap way to increase consumption of this product - reducing its losses, primarily due to the optimization of storage modes.

3. Despite the abundance of descriptions of the impact of various factors on the effectiveness of the storage process, the analytical expressions, which should be an integral part of mathematical models of this process are unknown.

4. To predict the state of the storage facility and adjustment modes of storage in the course of his proposed analytical relationships that let you create optimization and simulation models of the storage process.

5. The analytical curves were obtained thanks to the state information storage object obtained during the storage process itself.

\section{References}

1. Vinnikova, L. G., Dudkin, M. S., Petukhov, S. D. (1990). Influence of pishevih concentrates of fiber of bran on the technological properties of meat systems. Food technology. No 2-3. P. 52-54.

2. Dmitriev, A., Kotrowski, A., Salahina, E. (2007). Tradicionional products of soybean processing in the production of semi-finished products machines. Meat technology. No 9. P. 72-73.

3. Drozdovskaya, L. (2007). Latest technology in the production of semi-finished products. Meat technology. No $11.39 \mathrm{p}$.

4. DSTU 4437. (2005). Napupulot $\mathrm{m}+\mathrm{TA} \mathrm{m}$ yasoroslynn scan. TU.

5. Zhuravskaya, N., Alekhine, L., Treshnikov, L. (1985). Research and quality control of meat and meat products. Moscow. Agropromizdat, $296 \mathrm{p}$.

6. Kozlov, A. (2007). New possibilities in the production of natural products. Meat technology. No 8 . P. 40-41.

7. Kurchaeva, E., Maksimov I., Manusov, V. (2006). Vegetable protein sources in combined meat products. Food industry. No $1.90 \mathrm{p}$.

8. Kushnir, Y. (2004). Substances that increase the adhesion and the amount of water-binding capacity. The products and ingredients. No 5 (6). P. 12-13. 
9. Lisitsin, A., Litvinova, E., Kotenkova, I., Osipova, G. (2002). Rheological characteristics of ground beef with alginates. The meat industry. No 7. P. 50-52.

10. Nikolaev, S., Kuznetsova, Y., Bobreneva, I. (2004). Modeling of the formulations of meat chopped semi-finished products. Meat industry. No 10. P. 51-53.

11. Antipova, L. V., Glotova, I. A., Rogov, I. A. (2001). Research methods of meat and meat products. Moscow. Ear. 376 p.

\section{Список літератури}

1. Винникова Л. Г., Дудкин М. С., Патюков С. Д. Влияние концентратов пищевих волокон отрубей на технологические свойства мясных систем. Известия ВУЗов. Пищевая технология. 1990. №2-3. С. 52-54.

2. Дмитриев А., Котровский А., Салахина E. Традиционние продукти переработки сои в производстве мясних полуфабрикатов. Мясные технологии. 2007. №9. С. 72-73.

3. Дроздовская Л. Новейшие технологи в производстве полуфабрикатов. Мясные технологии. 2007. № 11.39 c.

4. ДСТУ 4437:2005. Напівфабрикати м'ясні та м'ясо-рослинні січені. ТУ.

5. Журавская Н., Алехина Л., Отрешникова Л. Исследование и контроль качества мяса и мясопродуктов. Москва. Агропромиздат, 1985. 296 с.

6. Козлов $A$. Новые возможности в производстве натуральных полуфабрикатов. Мясные технологии. 2007. № 8. С. 40-41.

7. Курчаева Е., Максимов И., Манжесов В. Растительные источники белка в комбинированных мясных продуктах. Пищевая промышленность. 2006. № 1. С. 90.

8. Кушнир Ю. Вещества, повышающие адгезию и величину водосвязывающей способности. Продукты \& ингредиенты. 2004. № 5 (6). С. 12-13.

9. Лисицин А., Литвинова Е., Коченкова И., Осипова $Г$. Реологические характеристики мясного фарша с альгинатами. Мясная индустрия. 2002. № 7. C. $50-52$.

10. Николаева С., Кузнецова Ю., Бобренева И. Моделирование рецептур мясных рубленых полуфабрикатов. Мясная индустрия. 2004. № 10. C. 51-53.

11. Антипова Л. В., Глотова И. А., Рогов И. А. Методы исследования мяса и мясных продуктов. Москва. Колос. 2001. 376 с.

\section{ВИЗНАЧЕННЯ ВПЛИВУ РЕЖИМІВ ЗБЕРІГАННЯ ПЛОДООВОЧЕВОЇ ПРОДУКЦІЇ НА ІІЇ СТАН B. А. Музиченко}

Анотація. Проаналізовано рівні споживання плодоовочевої продукції та іiі втрат. Запропоновано використовувати інформацію від об'єкта зберігання про його стан для визначення впливу умов зберігання на цей стан. Проаналізовано способи отримання інформації від продукції рослинництва про іiі стан. Обгрунтовано необхідність надання інформації про стан об'єкта зберігання, залежно цього стану від режимів зберігання, а також впливу режимів зберігання на його тривалість в аналітичному вигляді. Обгрунтовано необхідність використання для підвищення ефективності зберігання як оптимізаційне, так i імітаційне математичне моделювання впливу зовнішніх впливів зберігається на продукцію. Отримано аналітичний опис залежності стану продукції від режимів зберігання, що дозволяють визначати один 3 режимів зберігання в залежності від планової ефективності зберігання при фіксованих інших режимах. На прикладі залежності окислювально-відновного потенціалу рослинної сировини з соковитими тканинами від тривалості зберігання викладена методика ii апроксимації експонентою. Отримана залежність ефективності зберігання від ії режимів, яка може служити цільовою функцією при оптимізації цих режимів. Створені передумови для імітаційного моделювання впливу зовнішніх впливів на ефективність зберігання та оптимізації режимів зберігання за критерієм мінімуму втрат, якщо регульованими змінними є тривалість зберігання, а також температура і вологість повітря в сховищі. Математичні моделі процесів зберігання дають можливість корегувати режими в процесі зберігання і прогнозувати стан зберігаються об'єктів.

Ключові слова: сільськогосподарська продукція, зберігання, ефективність, режими, математичне моделювання.

\section{ОПРЕДЕЛЕНИЕ ВЛИЯНИЯ РЕЖИМОВ ХРАНЕНИЯ ПЛОДООВОЩНОЙ ПРОДУКЦИИ НА ЕЁ СОСТОЯНИЕ \\ В. А. Музыченко}

Аннотация. Проанализированы уровни потребления плодоовощной продукции и её потерь. Предложено использовать информацию от объекта хранения о его состоянии для определения влияния условий хранения на это состояние. Проанализированы способы получения информации от продукции растениеводства о её состоянии. Обоснована необходимость предоставления информации о состоянии объекта хранения, зависимости этого состояния от режимов хранения, а также влияния режимов хранения на его продолжительность в аналитическом виде. Обоснована необходимость использования для повышения эффективности хранения как оптимизационное, так и имитационное математическое моделирование влияния внешних воздействий на хранящуюся продукцию. Получено аналитическое описание зависимости состояния продукции от режимов хранения, позволяющие определять один из режимов хранения в зависимости от плановой эффективности хранения при фиксированных остальных режимах. На примере зависимости окислительно-восстановительного потенциала растительного сырья с сочными тканями от продолжительности хранения изложена методика её аппроксимации экспонентой. Получена зависимость эффективности хранения от её режимов, которая может служить целевой функцией при оптимизации этих режимов. 
Созданы предпосылки для имитационного моделирования влияния внешних воздействий на эффективность хранения и оптимизации режимов хранения по критерию минимума потерь, если регулируемыми переменными являются продолжительность хранения, а также температура и влажность воздуха в хранилище. Математические модели процессов хранения дают возможность корректировать режимы в процессе хранения и прогнозировать состояние хранящихся объектов.

Ключевые слова: сельскохозяйственная продукция, хранение, эффективность, режимы, математическое моделирование.

V. A. Muzychenko ORCID 0000-0003-2135-8522. 
